Elżbieta Izabela MISIEWICZ, PhD

Faculty of Economics and Management, University of Bialystok e-mail: e.misiewicz@uwb.edu.pl

ORCID: 0000-0003-2166-6322

\author{
Ewa MAGREL, PhD \\ Faculty of Economics and Management, University of Bialystok \\ e-mail: e.magrel@uwb.edu.pl \\ ORCID: 0000-0003-3538-4123
}

DOI: $10.15290 /$ oes.2018.04.94.17

\title{
EVALUATION OF VOIVODESHIPS IN SCOPE OF ENTREPRENEURSHIP DEVELOPMENT WITH THE USE OF SELECTED METHODS
}

\begin{abstract}
Summary
The transformation of the Polish economy, which is still in progress, draws attention to the existing differences between the voivodeships in the scope of entrepreneurship development. Despite the comparable initial situation in 1989, after almost 30 years of transformation, it is possible to indicate general development trends across the country, but over time disproportions in the level of development in individual voivodeships have become apparent.

For this reason, the article attempts to assess voivodships in terms of entrepreneurship development using the taxonomic analysis, the TOPSIS method and the principal components analysis.

The adopted concept of the article made it possible to verify the hypothesis put in the paper, according to which there is a clear division in Poland into voivodeships with a higher and lower level of entrepreneurship development.

The analysis conducted in the article allowed to identify the leaders of entrepreneurship on a regional level and also showed that there are clear disproportions in the level of entrepreneurship development in the eastern and western part of the country.
\end{abstract}

Key words: entrepreneurship, development of entrepreneurship in voivodeships, numerical taxonomy, TOPSIS, principal components analysis

JEL Classification: C10, D22, L26

\section{Introduction}

Transformations of the Polish economy conducted over the period of almost 30 years influenced various areas, especially the state of the Polish entrepreneurship. The transition from the centrally planned economy, fully controlled by the state, to the market one required changes, e.g. in the structure of production, consumption 
and employment. Until 1989, Poland was dominated by the industry sector, mainly the extractive industry and the arms industry. Private ownership was present on a very limited scale. The results of the centrally controlled economy were e.g., the existence of the demand exceeding the supply and growing social discontent.

The breakthrough for the Polish economy came in 1989, when, for the first time in post-war Poland, free parliament elections took place. T. Mazowiecki became the Prime Minister, while the recovery of the Polish economy was entrusted to L. Balcerowicz - the Minister of Finance. Due to the package of ten acts regarding the bases of the country's functioning, the centrally controlled economy started its transformation into the market economy, led by the rules of supply and demand, while most state companies were privatized.

The changes of the year 1989 greatly altered the shape, structure and functioning of Polish companies. Nevertheless, despite a similar initial situation, the level of entrepreneurial development in particular voivodeships varies greatly at the moment. It needs to be noted that there is a visible correlation between the voivodeships' potential and entrepreneurial actions - on one hand, entrepreneurial actions may influence the level of development of a particular voivodeship, on the other hand, the regional level of development may stimulate entrepreneurship. It should be also emphasized that entrepreneurship is the carrier of innovation and competitiveness of cities, voivodeships, and, finally, of the whole country.

The issue of inter-regional disproportions in the level of entrepreneurship is addressed by scientists, entrepreneurs and politicians. Every year, the Ministry of Development publishes a report Entrepreneurship in Poland. Moreover, the Polish Agency for Enterprise Development has been dealing with the issue of entrepreneurship for many years, conducting numerous studies and analyses, and publishing every year a report of the study Global Entrepreneurship Monitor Polska. The issue of entrepreneurship in regards to inter-regional differences has been studied by, e.g. Z. Makieła [2018], M. Jabłońska [2017] or J. Korol et al. [2016].

The article has been divided into two parts. The first one has a descriptive character and focuses on the diagnosis of enterprises' condition in Poland. The second part has an empirical character and aims to assess the differentiation of the entrepreneurial level in particular voivodeships. Three methods were used to conduct the study: the taxonomic analysis, the TOPSIS method and the principal components analysis. The taxonomic analysis allows to conduct a multidimensional assessment of the entrepreneurial level of the regions. It enables to group the voivodeships in relatively homogenous classes and to develop a ranking in terms of the level of entrepreneurship. The TOPSIS method allowed the linearization of voivodeships in terms of the entrepreneurial level through synthetic measures of variable data. The principal components method is frequently used to reduce data or space features and to order units in $p$-dimensional space and for this reason, it was used for linear ordering of the voivodehips in terms of the entrepreneurship development. 


\section{Enterprise sector in Poland}

The dynamic development of private investment in Poland was connected with the systematic transformation, which forced companies to adapt to the changing conditions. The changes conducted in Poland since autumn 1989 were aimed at developing the market economy targeted towards serious structural transformations, enabling faster economic growth with special reference to the relation between democracy, market and economic development, opening up to the outside world and the economic strategy in the context of economic reforms [Dynamika transformacji..., 1997, p. 9].

According to prof. Z. Sadowski, the problem of transformation in terms of entrepreneurship was the creation of the new system of economic entities able to function in the competitive conditions of the market economy and the creation of the proper system of market signals, such as prices, exchange rates, interest rates [Sadowski, 2005, pp. 23-24].

The first years of Polish transformation were characterized by the significant dynamics of the enterprise sector's growth - over a few years the number of enterprises increased dynamically. In 1990 there were 426 thou. private enterprises, in 1995 - 2099 thou., in 1999 - 3013 thou. The share of the SMEs sector in the general number of enterprises increased in the ' 90 s of the $20^{\text {th }}$ century and by the end of the decade constituted $90 \%$. Family companies based solely on the owners' savings were of special importance. At the same time, there were various problems connected with state companies' functioning which could not cope with the growing competition, growing costs and decreasing sales in the new conditions of the market economy [Lenik, Krzywonos, 2015, pp. 117-118]. The solution to the state companies' problems was to be the initiated process of privatization of that group of enterprises.

In the next phase - at the turn of the century - consolidation processes of large entities intensified and Polish activity in terms of setting up private companies increased. In the years 2000-2003 the number of enterprises increased by about half a million, most of which constituted natural persons conducting business activities. The next landmark in the development of Polish entrepreneurship was the year 2004 and the accession of Poland to the European Union. It gave access to the EU funds and external sources of funding, increased demand on Polish products on the EU market, improved access to credit, improved financial results and increased export opportunities. In 2004-2007 companies focused on making use of prosperity and on investing in expanding their activities [Lenik, Krzywonos, 2015, pp. 117-118].

The analysis of Polish enterprises in terms of business profile indicates that the process of transformation is also the period of crucial changes in the structure of goods production and services. Generally, it is reflected in the higher share of the services sector and the changes in the structure of the industrial production - the share of the branches producing materials and raw materials decreased, while the share of the industrial processing products increased [Skowronek, 2010, p. 156]. The services sector in Poland currently employs almost 60\% workers (while in 1989 it 
employed about 30\%) and constitutes 64\% in Polish GDP returns. The increase in the services sector's importance asserts the transformation of the centrally planned economy into the market one and its modernization.

The transformation period definitely changed the economic potential of the enterprise sector, the ownership structure, as well as the product and technology structure. The issue of the enterprise definition was also clarified.

The binding enterprise definition was drawn up in the Act of 2 July 2004, The Business Activities Freedom Act [Ustawa, 2004, art. 104-109]. The included clauses on qualifying business entities are of quantitative character. The following categories of enterprises are distinguished:

- microenterprises, which include entities that in at least one of the last two financial years employed on yearly average fewer than 10 employees and whose annual net turnover from the sales of goods, services and products and financial operations did not exceed a PLN equivalent of EUR 2 million or the total assets of its balance sheet in one of those years did not exceed a PLN equivalent of EUR 2 million,

- small enterprises are entities that in at least one of the last two financial years employed on yearly average fewer than 50 employees and whose annual net turnover from the sales of goods, services and products and financial operations did not exceed a PLN equivalent of EUR 10 million or the total assets of its balance sheet in one of those years did not exceed a PLN equivalent of EUR 10 million,

- medium enterprises are entities that in at least one of the last two financial years employed on yearly average fewer than 250 employees and whose annual net turnover from the sales of goods, services and products and financial operations did not exceed a PLN equivalent of EUR 50 million or the total assets of its balance sheet in one of those years did not exceed a PLN equivalent of EUR 43 million,

- $\quad$ large enterprises are entities employing at least 250 employees and whose annual net turnover from the sales of goods, services and products and financial operations exceeds a PLN equivalent of EUR 50 million or the total assets of its balance sheet exceeds a PLN equivalent of EUR 43 million.

In the period from 2007 to 2017, the number of national economic entities increased by about $17 \%$, mainly due to the increase in the number of microenterprises (by about 18\% in 2017 compared to 2007) and due to the increase in the number of medium enterprises (by about 2\% in 2017 compared to 2007). In the analysed period, the number of small and large enterprises decreased by, respectively, $2 \%$ and $6 \%$ (table 1 ).

The current conditions in which Polish enterprises function are quite complex. This state is influenced, among others, by globalization and the accompanying process of internationalisation of all activities. Last years in business were also a period of increased changes in many areas of economic life, which forced compa- 
nies to search for new sources of competitiveness and for strategies ensuring the survival and development on the market [Strategiczna transformacja..., 2012, p. 7].

TABLE 1

\section{National economy entities in terms of the predicted number of workers in 2007 and 2017}

\begin{tabular}{|c|c|c|c|c|c|}
\hline $\begin{array}{c}\text { The number } \\
\text { of workers }\end{array}$ & $\mathbf{0 - 9}$ & $\mathbf{1 0 - 4 9}$ & $\mathbf{5 0 - 2 4 9}$ & over 250 & Total \\
\hline 2007 & 3502303 & 150128 & 28462 & 4715 & 3685608 \\
\hline 2017 & 4128611 & 147607 & 29154 & 4428 & 4309800 \\
\hline $\mathrm{i}_{2017 / 2007}$ & 1,18 & 0,98 & 1,02 & 0,94 & 1,17 \\
\hline
\end{tabular}

Source: [Zmiany strukturalne ..., 2008, p. 34; Zmiany strukturalne ..., 2018, p. 19].

The Polish economy is becoming more and more competitive and dynamic. In the last few years, the following trends have been observed in the Polish entrepreneurship [Raport o stanie ..., 2017, p. 4]:

1. The number of enterprises in Poland is growing systematically - every year over $1 / 3$ million of new enterprises are established and this number has stayed on a similar level for quite a long time. The analysis of the statistical data indicates that in the last decade the number of national economy entities has increased from 3685608 (December 2007) to 4309800 (December 2017), among which 4140861 belonged to the private sector in December 2017. In the analysed period, the number of state owned enterprises significantly decreased - from 572 in 2007 to 142 in 2017 r. [Zmiany strukturalne ..., 2018, pp. 18-19].

2. The quality of the Polish entrepreneurship is improving - Polish companies are contributing more and more to the development of social prosperity. Data indicates that they are producing a growing part of Polish GDP. An average company is systematically developing in the economic meaning - its productivity measured in income, added value and production is increasing. There is also a tendency for the improvement of the company structure from the legal forms' point of view. The share of enterprises as legal entities is growing more dynamically than their share as natural persons (table 2).

The largest group of the register entities is comprised of natural persons conducting business activity (about 75\% in 2007 and 66\% in 2017) preceding trading companies (about 7\% in 2007 and $11.9 \%$ in 2017) and partnerships (about $7.6 \%$ in 2007 and 6.4\% in 2017). However, the year 2017 observed a beneficial trend of decreasing the number of natural persons (the increase of about $8 \%$ in 2017 in relation to 2007) and increasing the share of companies, mostly the trading ones (the increase of about 108\% in 2017 in relation to 2007). 
TABLE 2

Enterprises according to the selected legal forms in 2007 and in 2017

\begin{tabular}{|l|c|c|c|}
\hline \multicolumn{1}{|c|}{$\begin{array}{c}\text { Enterprises according to the selected legal } \\
\text { forms }\end{array}$} & $\mathbf{2 0 0 7}$ & $\mathbf{2 0 1 7}$ & $\mathbf{i}_{\mathbf{2 0 1 7} / \mathbf{2 0 0 7}}$ \\
\hline State owned enterprises & $\mathbf{5 7 2}$ & $\mathbf{1 4 2}$ & $\mathbf{0 , 2 5}$ \\
\hline Trading companies & $\mathbf{2 5 8 2 9 9}$ & $\mathbf{5 3 7 2 7 3}$ & 2,08 \\
\hline joint-stock companies & $\mathbf{8 8 5 3}$ & $\mathbf{1 2 0 4 4}$ & 1,36 \\
\hline limited companies & 216887 & 451863 & 2,08 \\
\hline limited liability partnerships & 1086 & 2333 & 2,15 \\
\hline unlimited companies & 28587 & 36399 & 1,27 \\
\hline limited partnerships & 2632 & 30654 & 11,65 \\
\hline joint-stock special partnerships & 254 & 3980 & 15,67 \\
\hline Partnerships & $\mathbf{2 8 0 8 9 0}$ & $\mathbf{2 8 8 6 0 3}$ & 1,03 \\
\hline Cooperatives & $\mathbf{1 8 1 2 8}$ & $\mathbf{1 7 6 9 4}$ & 0,98 \\
\hline Foundations & $\mathbf{9 8 1 2}$ & $\mathbf{2 7 0 1 5}$ & 2,75 \\
\hline Associations and social organisations & $\mathbf{8 0 6 3 6}$ & $\mathbf{1 2 0 9 3 1}$ & 1,50 \\
\hline Natural persons conducting business activity & $\mathbf{2 7 8 7 6 5 0}$ & $\mathbf{3 0 0 1 3 5 3}$ & 1,08 \\
\hline
\end{tabular}

Source: [Zmiany strukturalne ..., 2008, pp. 30-314; Zmiany strukturalne ..., 2018, p. 18.]

3. The openness of entrepreneurs and their focus on development are increasing. The companies are becoming international - the percentage of exporters and the average value of exports is growing, as well as the use of opportunities granted by the Internet presence. Despite some fluctuation, the percentage of companies conducting export activities regarding goods in 2008-2015 keeps growing (the increase from 3.3\% to 4.4\%). In 2010-2015, the export of an average Polish exporter of goods or services increased dynamically [Raport o stanie ..., 2017, p. 6].

However, apart from positive tendencies, some less beneficial trends can be observed on the enterprise market as well. One of them is a downward trend regarding the number of employees of an average company, which has been observed since 2010. The reason might be the considerable increase in the number of new companies, which employ people more rarely and in smaller numbers [Raport o stanie ..., 2017, p. 4].

In the group of active non-financial companies, 1914 thous. non-financial companies conducted business activity in Poland in 2015 (the newest available data), which was $3.9 \%$ more than the previous year. As in the previous years, microenterprises constituted the largest group of non-financial enterprises $-96 \%$. The percentage of small, medium and large entities constituted respectively: $3.0 \%, 0.8 \%$ and $0.2 \%$. Therefore, there have been no positive changes in the last years regarding the size structure of the companies, which is characterized by a larger percentage of microenterprises (0-9 employees) at the expenses of small companies 10-49 employees), in comparison to the average in the EU [Przedsiebiorczosic $w$ Polsce, 2017, p. 7]. 
According to the Central Statistical Office data regarding non-financial enterprises conducting business activity, the largest percentage of entities conducts trading activity (26.0\% of all active enterprises). The following kinds of activity according to their popularity among active entities are: construction activity $(12.8 \%)$, professional, scientific and technical activity (12.7\%), industrial activity (10.4\%). In the case of SMEs sector, this structure is virtually the same [Przedsiebiorczosíc $w$ Polsce, 2017, p. 53].

From the regional point of view, the largest number of active enterprises (as in the previous years) is situated in Mazowieckie (17.9\% of all entities), Śląskie (11.1\%), Wielkopolskie $(10.3 \%)$ and Małopolskie $(9.3 \%)$ Voivodeships. The analysis of the ratio of the number of enterprises to 1000 inhabitants indicates that, as in the previous years, results lower than the national average were achieved by the following Voivodeships: Podkarpackie, Lubelskie, Warmińsko-mazurskie, Świętokrzyskie, Podlaskie, Opolskie, Kujawsko-pomorskie, Lubuskie, Śląskie and Lódzkie [Præ̌edsiębiorczosic $w$ Polsce, 2017, p. 52]. The number of active enterprises per 1000 inhabitants is illustrated by chart 1 .

\section{The number of active enterprises per 1000 inhabitants (data from the end of 2015)}

\section{CHART 1}

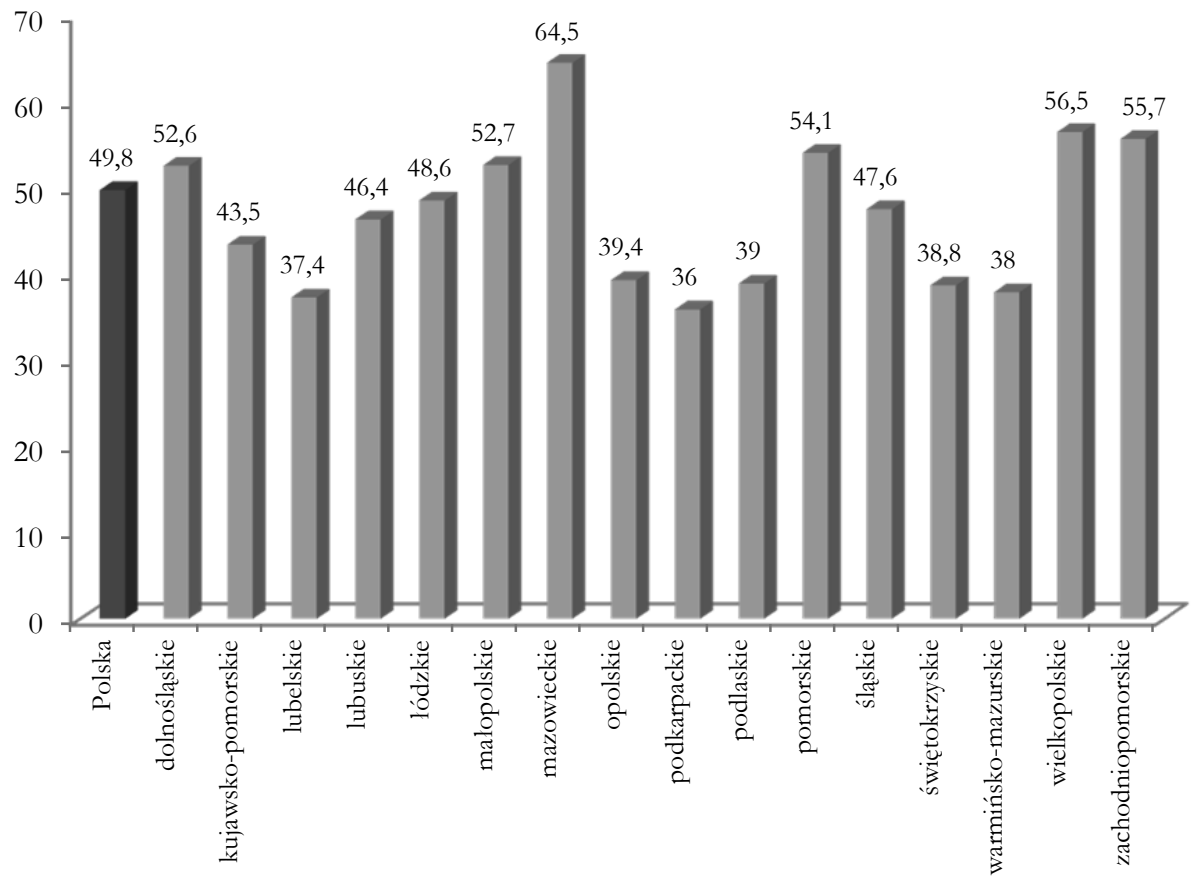


The further part of the article constitutes an attempt at the overall assessment of voivodeships' attractiveness in terms of entrepreneurship development. The following methods were used to achieve this aim: the taxonomic analysis, the TOPSIS method and the principal components analysis.

\section{The study on voivodeships' attractiveness using different methods}

\subsection{The taxonomic analysis}

The basic aim of the taxonomic analysis is the assessment of the variation level of objects described using the set of statistical characteristics and establishing the clusters of these objects in terms of similar development, as well as defining homogenous classes of objects in terms of their characteristics. Moreover, the taxonomic study may provide a lot of additional information, greatly contributing to the general knowledge about the studied category of objects. For instance, it is possible to assess the involvement of each object in the development of their collectivity, to visualize the problem graphically or to define the coherence, inner homogeneity and stability of the derived group [Młodak, 2006, p. 26].

In the article, the analysis of the individual indicators will be conducted, which will allow to compare the level of the development of entrepreneurship and to determine each voivodeship's position in the studied structure, in terms of each analysed characteristic. In the case of the taxonomic analyses, the particular individual indicators are aggregated into the synthetic indicator, which enables the linear ordering of the voivodeships in terms of the entrepreneurship development; Ward's method will be used as well to aggregate the voivodeships in terms of the similar level of the studied characteristic [Ward, 1963, pp. 236-244]. Classifying voivodeships into the same cluster will indicate similarity of these objects in terms of a certain set of characteristics. Objects belonging to different clusters will be dissimilar.

Aggregation is based on the distance measured between the clusters. One group is comprised of the nearest clusters. In the article, the distance was measured using Euclidean metric. Dendrogram is the graphic illustration of the analysed objects set's division into groups.

Variables used to decribe the level of entrepreneurship in each voivodeship are presented in table 3 .

The selection of variables was based on the report Entrepreneurship in Poland [Przedsiebiorczosí w Polsce, 2017], which is published annually by the Ministry of Development. Apart from the attempt at the total analysis of Polish enterprises and their environment, the report also contains statistical data concerning the enterprise sector and the ranking of voivodeships in terms of the synthetic assessment of the entrepreneurship development. The report's authors, while selecting data used for the comparative analysis of the level of enterprises in particular voivodeships in Poland, tried to eliminate variables, which would make it possible to additionally reward the given voivodeship for the economic potential of the region (e.g., the 
global size of investment outlays or of the enterprise sector's income), focusing on, for instance, the dynamics of the development process [Przedsiebiorczosic $w$ Polsce, 2017, p. 163]. The other criteria of the selection of variables were not stated in the report. The authors of this article, basing on the set of variables stated in the report (table 3), attempted to broaden the scope of the research by dividing the voivodeships into the groups of objects on a similar level of entrepreneurship. Both the authors of the report and the authors of the article used the programme Taksonomia numeryczna by K. Kolenda for calculations. Numerical data for each voivodeship is presented in table 4 . The taxonomic analysis included in the report Entrepreneurship in Poland [Przedsiebiorczosic $w$ Polsce, 2017] inspired the research on the level of entrepreneurship in Poland in the voivodeships and also the attempt to verify the results of the report using the TOPSIS method and the main component analysis. In terms of the taxonomic method, the research is of a secondary nature.

TABLE 3

Variables characterizing the degree of entrepreneurship in 16 voivodeships

\begin{tabular}{|c|l|}
\hline Variable & \multicolumn{1}{|c|}{ Variable's description } \\
\hline X1 & $\begin{array}{l}\text { The number of newly registered national economy entities in the REGON } \\
\text { register per 1 thou. of people (2016) }\end{array}$ \\
\hline X2 & The number of active non-financial enterprises per 1 000 inhabitants (2015) \\
\hline X3 & Investment volume in enterprises in relation to GDP (2014) \\
\hline X4 & $\begin{array}{l}\text { Natural persons conducting activity in rural areas per 100 thou. working-age } \\
\text { people (2016) }\end{array}$ \\
\hline X5 & Income per 1 entity in the SMEs sector (non-financial enterprises) (2015) \\
\hline X6 & $\begin{array}{l}\text { 3-year income dynamics of all activities of small and medium companies } \\
\text { (2016, 2013 = 100, current prices) }\end{array}$ \\
\hline X7 & $\begin{array}{l}\text { 3-year investment outlays dynamics of small and medium companies (2016, } \\
\text { 2013=100, current prices) }\end{array}$ \\
\hline X8 & $\begin{array}{l}\text { 3-year dynamics of the number of employees in small and medium } \\
\text { companies (2016, 2013 = 100) }\end{array}$ \\
\hline X9 & $\begin{array}{l}\text { The average share of innovative enterprises in the total number of industrial } \\
\text { and services sector enterprises (2015) }\end{array}$ \\
\hline
\end{tabular}

Source: [Przedsiębiorczość w Polsce, 2017, p. 165]. 
TABLE 4

Data used in the ranking of voivodeships in terms of the level of the development of entrepreneurship

\begin{tabular}{|l|c|c|c|c|c|c|c|c|c|}
\hline \multicolumn{1}{|c|}{ Variable } & $\mathbf{X} 1$ & $\mathbf{X} 2$ & $\mathbf{X} 3$ & $\mathbf{X} 4$ & $\mathbf{X} 5$ & $\mathbf{X 6}$ & $\mathbf{X} 7$ & $\mathbf{X 8}$ & $\mathbf{X 9}$ \\
\hline Dolnodeshaskie & 9.92 & 52.6 & 0.105 & 13 & 1030 & 114 & 103 & 106 & 0.142 \\
\hline Kujawsko-pomorskie & 7.69 & 43.5 & 0.090 & 11 & 1089 & 105 & 88 & 99 & 0.125 \\
\hline Lubelskie & 6.69 & 37.4 & 0.073 & 10 & 948 & 107 & 82 & 101 & 0.135 \\
\hline Lubuskie & 9.18 & 46.4 & 0.071 & 12 & 979 & 81 & 130 & 102 & 0.116 \\
\hline Lódzkie & 8.17 & 48.6 & 0.093 & 12 & 994 & 108 & 133 & 104 & 0.125 \\
\hline Małopolskie & 9.62 & 52.7 & 0.077 & 13 & 1108 & 99 & 94 & 106 & 0.152 \\
\hline Mazowieckie & 12.69 & 64.5 & 0.088 & 16 & 1711 & 109 & 134 & 106 & 0.145 \\
\hline Opolskie & 6.29 & 39.4 & 0.106 & 11 & 1071 & 109 & 76 & 101 & 0.150 \\
\hline Podkarpackie & 6.74 & 36.0 & 0.085 & 9 & 1005 & 110 & 75 & 102 & 0.142 \\
\hline Podlaskie & 6.81 & 39.0 & 0.073 & 10 & 1061 & 106 & 87 & 108 & 0.153 \\
\hline Pomorskie & 11.13 & 54.1 & 0.099 & 14 & 1138 & 108 & 81 & 103 & 0.126 \\
\hline Śląskie & 7.57 & 47.6 & 0.090 & 12 & 1204 & 104 & 91 & 101 & 0.131 \\
\hline Świętokrzyskie & 7.28 & 38.8 & 0.067 & 11 & 920 & 104 & 102 & 101 & 0.115 \\
\hline Warmińsko-mazurskie & 7.21 & 38.0 & 0,076 & 10 & 900 & 109 & 105 & 102 & 0.113 \\
\hline Wielkopolskie & 9.71 & 56.5 & 0.086 & 14 & 1219 & 114 & 114 & 106 & 0.130 \\
\hline Zachodniopomorskie & 10.41 & 55,7 & 0.081 & 15 & 927 & 108 & 78 & 107 & 0.158 \\
\hline $\begin{array}{l}\text { The coefficient of } \\
\text { variation }\end{array}$ & $22 \%$ & $18 \%$ & $14 \%$ & $16 \%$ & $18 \%$ & $7 \%$ & $21 \%$ & $3 \%$ & $11 \%$ \\
\hline
\end{tabular}

Source: [Przedsiębiorczosić w Polsce, 2017, p. 165].

On the basis of the nine variables presented in table 4., the synthetic measure of the level of development of entrepreneurship in particular voivodeships was constructed. Then, using the linear ordering method - Perkal's method [Florek et al., 1956], the synthetic indicators of the level of development of entrepreneurship were calculated. The following formula was used for the calculations:

$$
P_{n}=\frac{1}{k} \sum_{m=1}^{k} t_{n m}=\frac{1}{k} \sum_{m=1}^{k} \frac{x_{n m}-\overline{x_{m}}}{s_{m}}
$$

where:

$\mathrm{P}_{\mathrm{n}}$ - index of the level of entrepreneurship in $\mathrm{n}$ voivodeship,

$t_{n m}-$ standarised value of $m$ characteristic in $n$ voivodeship,

$\mathrm{k}$ - number of characteristics comprising the synthetic indicator,

$\mathrm{m}-$ number of indicator in $\mathrm{n}$ voivodeship.

Then, on the basis of the calculated synthetic measure, the ranking of voivodeships in terms of the level of development of entrepreneurship was prepared. All the 
variables were regarded as stimulants and each of them was treated as equally important. The results were compiled in table 5 .

TABLE 5

Ranking of voivodeships in terms of the development of entrepreneurship

\begin{tabular}{|c|l|c|}
\hline $\begin{array}{c}\text { Place in the } \\
\text { ranking }\end{array}$ & \multicolumn{1}{|c|}{ Voivodeship } & Synthetic measure \\
\hline 1 & Mazowieckie & 3.298 \\
\hline 2 & Zachodniopomorskie & 2.270 \\
\hline 3 & Dolnoślaskie & 1.902 \\
\hline 4 & Wielkopolskie & 1.547 \\
\hline 5 & Lódzkie & 1.168 \\
\hline 6 & Pomorskie & 0.778 \\
\hline 7 & Małopolskie & 0.448 \\
\hline 8 & Opolskie & -0.752 \\
\hline 9 & Podlaskie & -0.786 \\
\hline 10 & Śląskie & -0.896 \\
\hline 11 & Lubuskie & -1.114 \\
\hline 12 & Warmińsko-mazurskie & -1.254 \\
\hline 13 & Lubelskie & -1.544 \\
\hline 14 & Kujawsko-pomorskie & -1.617 \\
\hline 15 & Świętokrzyskie & -1.651 \\
\hline 16 & Podkarpackie & -1.796 \\
\hline
\end{tabular}

Source: own elaboration in the programme Taksonomia numeryczna [Kolenda, 2006].

The next activity was dividing the voivodeships into groups on a similar level of entrepreneurship. In order to achieve that, a dendrogram for the whole structure (16 voivodeships) was constructed, which was later used to divide the voivodeships into groups of similar objects. The obtained results are presented in chart 2.

The number of particular clusters is varied. Attention should be paid to two single-component clusters. The Mazowieckie Voivodeship differed from all the other voivodeships in terms of its characteristics - almost all analysed values were the highest in that voivodeship. Another single-component cluster which was found unlike all the others was the Lubuskie Voivodeship.

For the purpose of further analyses, the separation was made on level 7 (the distance after scaling up), which allowed to extract 4 groups of clusters. The obtained results are presented in table 6 . 
CHART 2

Dendrogram presenting the division of the voivodeships in terms of the entrepreneurship development

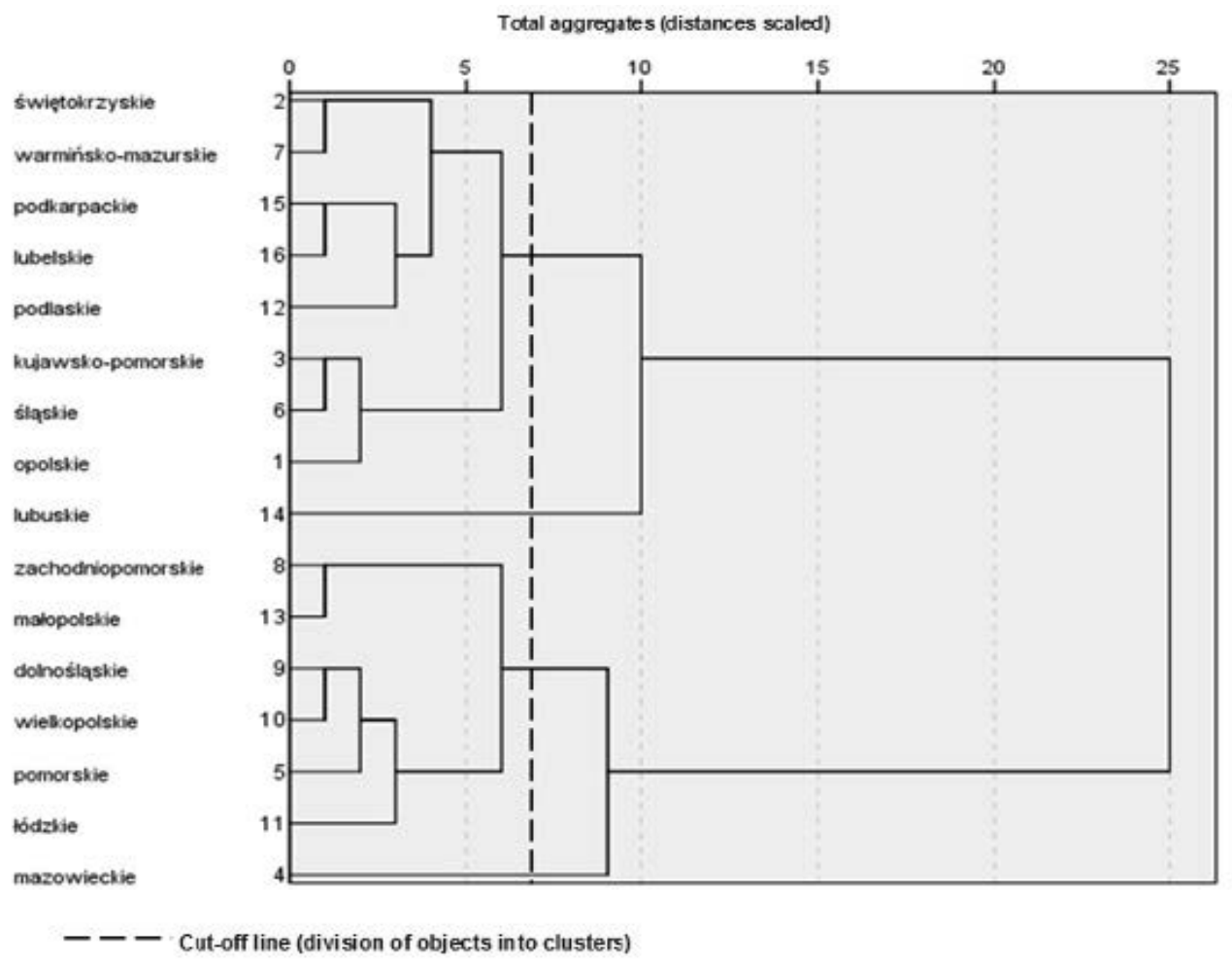

Sorce: own elaboration using the SPSS programme.

TABLE 6

Grouping the voivodeships using Ward's method in terms of the level of the development of entrepreneurship

\begin{tabular}{|c|l|}
\hline Group & \multicolumn{1}{|c|}{ Voivodeships belonging to each group } \\
\hline I & Mazowieckie \\
\hline II & $\begin{array}{l}\text { Zachodniopomorskie, Małopolskie, Wielkopolskie, Dolnośląskie, Pomorskie, } \\
\text { Lódzkie }\end{array}$ \\
\hline III & Lubuskie \\
\hline IV & $\begin{array}{l}\text { Podlaskie, Podkarpackie, Śląskie, Kujawsko-pomorskie, Opolskie, } \\
\text { Swwiętokrzyskie, Warmińsko-mazurskie, Lubelskie }\end{array}$ \\
\hline
\end{tabular}

Source: own elaboration. 
The voivodeships presented in table 6 . include regions on a similar level of entrepreneurship in terms of analysed characteristics. However, belonging to a particular group does not indicate the level of development of the included objects. By comparing the voivodeships ranking and the names of regions belonging to the clusters, it is possible to determine the hierarchy of groups, however, it is necessary to remember that the division into groups does not always coincide with the linear order obtained by calculating the distance from the pattern.

Combined analysis of the data obtained in tables 5., 6. and chart 2. indicates that the Mazowieckie Voivodeship is the undeniable leader in terms of the entrepreneurship development. It ascertained its domination over the other regions by its strong advantage in terms of the number of the national economy entities newly registered in the REGON register per 1000 inhabitants, the number of natural persons conducting business in rural areas per 100 thou. working-age people and the revenue per 1 entity in the SMEs sector (non-financial enterprises).

The second group includes the voivodeships on the medium entrepreneurship level, whose advantage constitutes a relatively high number of the national economy entities newly registered in the REGON register per 1000 inhabitants, the number of active non-financial enterprises per 1000 inhabitants and the revenue per 1 entity in the SMEs sector (non-financial enterprises).

The Lubuskie Voivodeship comprises a separate third group, which means that the level of the analysed indicators in this region is so varied that it makes it impossible to assign it to a more numerous group; e.g. indicators regarding the number of the national economy entities newly registered in the REGON register per 1000 inhabitants or the 3-year investment outlays dynamics of small and medium companies achieve one of the highest levels in the country, while the revenue per 1 entity in the SMEs sector (non-financial enterprises) and the 3-year income dynamics of all activities of small and medium companies are defined by nearly the lowest figures among all the voivodeships.

The voivodeships in the fourth group are characterized by the lowest entrepreneurship level. Five out of eight voivodeships are the regions in eastern Poland. The reason of this situation is e.g. a low level of companies innovation.

\subsection{The TOPSIS method}

One of the methods of linear ordering of multi-characteristic objects is the TOPSIS method (Technique for Order Preference by Similarity to Ideal Solution) [Hwang, Yoon, 1981, pp. 10-12]. In this method, the distance of each multi-characteristic object from the pattern and anti-pattern is determined, and then, the linear ordering of these objects in conducted in accordance with the following stages [Hwang, Yoon 1981, pp. 307-327]:

Stage 1. Selection of indicators characterizing the entrepreneurship level based on substantive and statistical rationale.

The values of indicators in each voivodeship are set into a data matrix: 


$$
X=\left[x_{i k}\right]
$$

where:

$\mathrm{x}_{\mathrm{ik}}$ - value of $\mathrm{k}$ indicator of the entrepreneurship level in $\mathrm{i}$ voivodeship, $\mathrm{i}=1,2,3, \ldots, \mathrm{n}-$ number of voivodeships $(\mathrm{n}=16)$, $\mathrm{k}=1,2,3, \ldots, \mathrm{m}-$ number of indicators of the entrepreneurship level $(\mathrm{m}=9)$.

Stage 2. Normalization of the values of indicators of the entrepreneurship level in order to ensure comparability of simple characteristics. Normalization was based on equations:

- for stimulant for destimulant

$$
z_{i k}=\frac{x_{i k}-\min _{i}\left\{x_{i k}\right\}}{\max _{i}\left\{x_{i k}\right\}-\min \left\{x_{i k}\right\}} \quad z_{i k}=\frac{\max _{i}\left\{x_{i k}\right\}-x_{i k}}{\max _{i}\left\{x_{i k}\right\}-\min \left\{x_{i k}\right\}}
$$

where:

$\max _{i}\left\{x_{i k}\right\}_{-}$maximum value of $\mathrm{k}$ indicator of the entrepreneurship level,

$\min _{i}\left\{x_{i k}\right\}$-minimum value of $\mathrm{k}$ indicator of the entrepreneurship level, $\mathrm{i}=1,2,3, \ldots, \mathrm{n}$ - number of voivodeships,

$\mathrm{k}=1,2,3, \ldots, \mathrm{m}-$ number of indicators of the entrepreneurship level.

Stage 3. Calculating the Euclidean distance of the voivodeships from the pattern $\mathrm{z}^{+}=(1,1, \ldots, 1)$ and anti-pattern $\mathrm{z}^{-}=(0,0, \ldots, 0)$ in accordance with equations:

$$
d_{i}^{+}=\sqrt{\sum_{k=1}^{m}\left(z_{i k}-z_{i k}^{+}\right)^{2}} \quad d_{i}^{-}=\sqrt{\sum_{k=1}^{m}\left(z_{i k}-z_{i k}^{-}\right)^{2}} \quad \text { dla } \quad \mathrm{i}=1,2,3, \ldots, \mathrm{n} .
$$

Stage 4. Determining the value of the synthetic meter of the entrepreneurship level in accordance with the pattern:

$$
q_{i}=\frac{d_{i}^{-}}{d_{i}^{+}+d_{i}^{-}} \text {dla } \mathrm{i}=1,2,3, \ldots, \mathrm{n} .
$$

Measure $\mathrm{q}_{\mathrm{i}}$ takes the following values $<0,1>$ and the higher the value, the higher the entrepreneurship level of the studied voivodeship is.

Stage 5. Linear ordering and typology of the voivodeships in terms of the level of entrepreneurship development. The typology was based on the k-average method, which entails dividing the whole set of objects into groups, in a way which maximises the variance between the groups and minimises the variance within the groups. The concept of the k-average method was formulated in the 50's by T. Dalenius [Cox, 1957, pp. 543-547]. 
By using the TOPSIS method, the values of the synthetic indicators for each voivodeships were estimated and the results are presented on chart 3 .

CHART 3

The values of the synthetic indicator obtained by using the TOPSIS method

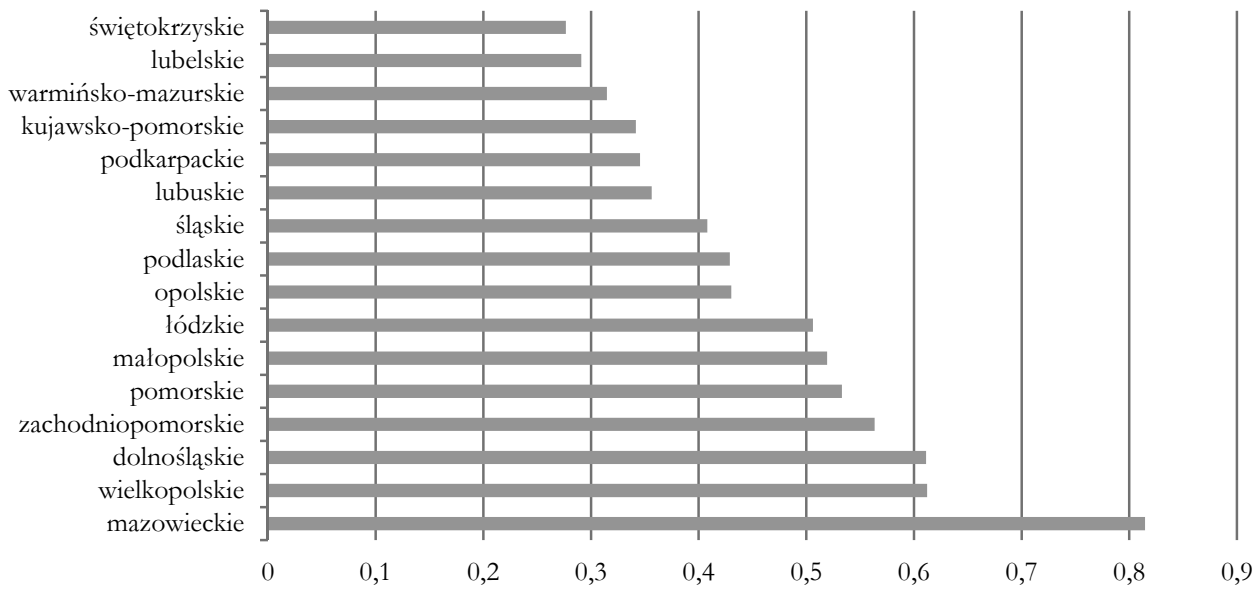

Source: own elaboration.

The highest value of the synthetic indicator and, therefore, the highest level of entrepreneurship development is observed in the Mazowieckie Voivodeship, while the lowest level of the studied phenomenon is observed in the Lubelskie and Świętokrzyskie Voivodeships.

Basing on the calculated values of the synthetic indicators and the k-average method, four typological groups of voivodeships were distinguished. The results are presented in table 7 .

TABLE 7

The division of the voivodeships into groups in accordance with the values of the synthetic indicator obtained by using the TOPSIS method

\begin{tabular}{|c|l|}
\hline Group & \multicolumn{1}{|c|}{ Voivodeships } \\
\hline I & Mazowieckie \\
\hline II & Wielkopolskie, Dolnoślaskie, Zachodniopomorskie \\
\hline III & Pomorskie, Małopolskie, Lódzkie, Opolskie, Podlaskie, Ślaskie \\
\hline IV & $\begin{array}{l}\text { Lubuskie, Podkarpackie, Kujawsko-pomorskie, Warmińsko-mazurskie, } \\
\text { Lubelskie, Świętokrzyskie }\end{array}$ \\
\hline
\end{tabular}

Source: own elaboration.

The first group with the highest level of the entrepreneurship development includes the Mazowieckie Voivodeship. This voivodeship is characterized by the 
above average values of the following indicators: the number of the national economy entities newly registered in the REGON register per 1000 inhabitants, the number of active non-financial enterprises per 1000 inhabitants, enterprise investment outlays in relation to GDP, the number of natural persons conducting business in rural areas per 100 thou. working-age people, the 3-year income dynamics of all activities of small and medium companies, the 3-year investment outlays dynamics of small and medium companies, the 3-year dynamics of the number of employees in small and medium companies.

The second group includes the voivodeships on the medium-higher level of the entrepreneurship development characterized by the above average values of the following variables: the number of active non-financial enterprises per 1000 inhabitants, the number of natural persons conducting business in rural areas per 100 thou. working-age people and the 3-year dynamics of the number of employees in small and medium companies.

The third group includes six voivodeships on the medium-lower level of the entrepreneurship development characterized by the general average values of the following variables: the 3-year income dynamics of all activities of small and medium companies and the average share of innovative enterprises in the total number of industrial and services sector enterprises.

The fourth group includes voivodeships on the low level of the entrepreneurship development characterized by much lower than average values of virtually all variables, apart from the variables regarding the 3-year income dynamics of all activities of small and medium companies, the 3-year investment outlays dynamics of small and medium companies and the average share of innovative enterprises in the total number of industrial and services sector enterprises.

\subsection{Principal components analysis}

The third applied method is the Principal Components Analysis, which is one of the statistical multidimensional analysis method. It is presumed that it was Pearson who, in his article On lines and planes of closest fit to systems of points in space from 1901, constructed theoretical bases of the principal components method. Some claim that the inventor of this method was Hotelling [Jajuga, 1993, p. 117].

Let us assume that we have $m$ of $\mathrm{X}_{\mathbf{j}}$ variables $(\mathrm{j}=1,2, \ldots, \mathrm{m})$ and we conduct observations on $n$ of homogenous objects $(\mathrm{i}=1,2, . ., \mathrm{n})$, which form $\mathrm{X}$ data matrix. The correlation matrix and the covariance matrix for these variables need to be defined. The idea of the principle components analysis is based on the orthogonal transformation of the system of the studied $X_{j}$ variables into the aggregate of newly observed $\mathrm{Y}_{1}$ variables, which are the linear combinations of those variables, as follows [Balicki, 2013, pp. 65-66]:

$$
\begin{aligned}
& \mathrm{Y}_{1}=\mathrm{w}_{11} \mathrm{X}_{1}+\mathrm{w}_{21} \mathrm{X}_{2}+\ldots+\mathrm{w}_{\mathrm{m} 1} \mathrm{X}_{\mathrm{m}} \\
& \mathrm{Y}_{2}=\mathrm{w}_{12} \mathrm{X}_{1}+\mathrm{w}_{22} \mathrm{X}_{2}+\ldots+\mathrm{w}_{\mathrm{m} 2} \mathrm{X}_{\mathrm{m}} \\
& \ldots \\
& \mathrm{Y}_{\mathrm{k}}=\mathrm{w}_{1 \mathrm{k}} \mathrm{X}_{1}+\mathrm{w}_{2 \mathrm{k}} \mathrm{X}_{2}+\ldots+\mathrm{w}_{\mathrm{mk}} \mathrm{X}_{\mathrm{m}}
\end{aligned}
$$


in the general form, this set may be expressed as:

$$
Y_{l}=w_{1 l} X_{1}+w_{2 l} X_{2}+\ldots+w_{m l} X_{m}=\sum_{j=1}^{m} w_{j l} X_{j} \text { for } 1=1 \ldots, \mathrm{k}=\mathrm{m}
$$

The new $Y_{1}$ variables are called the principle components of $X_{j}$ variables, $w_{j l}$ coefficients are composite loads. Composite variables are a combination of initial characteristics and contain some information provided by particular characteristics, therefore, they are of a synthetic characteristics nature. They are uncorrelated, the sum of the squares of a particular coefficient $\mathrm{w}_{\mathrm{jl}}$ combination equals one, and the sum of the $Y_{1}$ composite variance equals the general $X_{j}$. variables variance. The basic aim of the principal components analysis is identifying the correlation structure by creating a completely new set of variables, which could, wholly or in part, substitute the original set of variables. The principal components method also has other applications. It can be used to study correlation between the variables of a specified set, to reduce data or reduce characteristics space, to order entities in $p$-dimensional space, to assign entities to previously divided groups, to recognise atypical entities [Balicki, 2013, pp. 66-68].

By using the principal components method, the values of the synthetic indicators for particular voivodeships were assessed, arranged in ascending order and presented on chart 4.

CHART 4

\section{The values of the synthetic indicator obtained by using the principal components analysis}

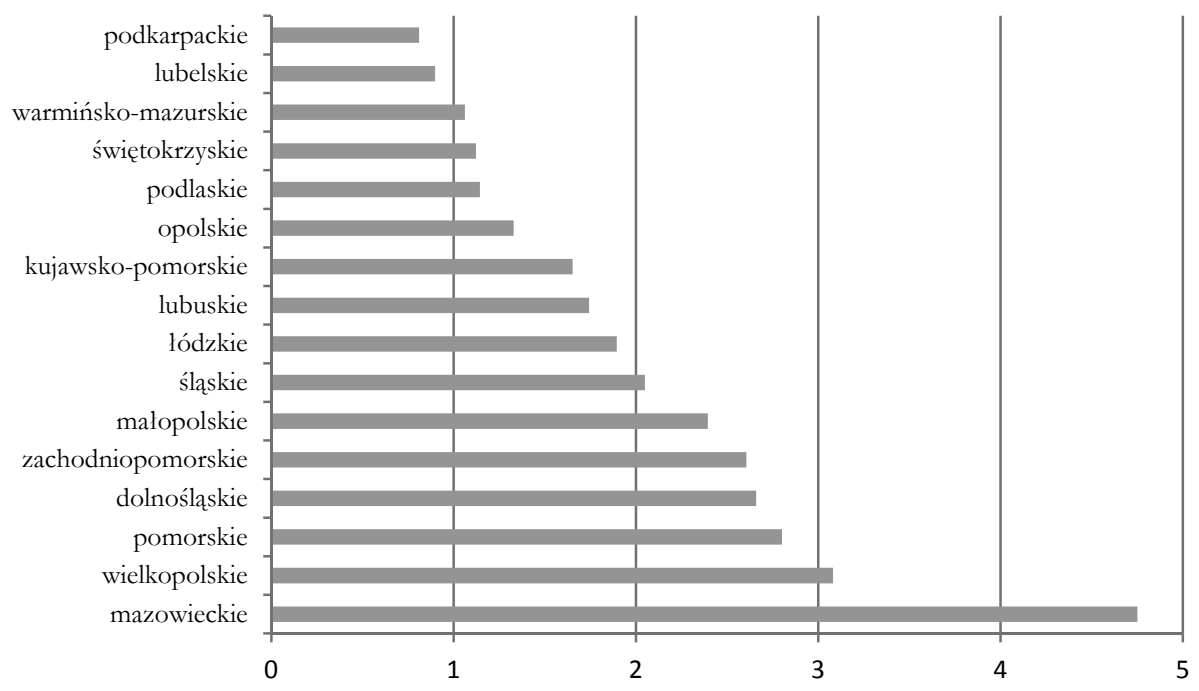

Source: own elaboration. 
The highest value of the synthetic indicator and, therefore, the highest level of the entrepreneurship development is observed in the Mazowieckie Voivodeship, while the lowest in the Lubelskie and Podkarpackie Voivodeships.

As when using the TOPSIS method, basing on the k-average method, four typological groups of voivodeships were distinguished in terms of the level of the entrepreneurship development. The results are presented in table 8 .

The first group with the highest level of the entrepreneurship development includes the Mazowieckie Voivodeship, which is characterized by very high values of 8 out of 9 variables, which were the bases of the analysis (apart from the variable of enterprises investment outlays in relation to GDP, whose value is lower than the average).

TABLE 8

The division of the voivodeships into groups in accordance with the values of the synthetic indicator obtained by means of the principal components analysis

\begin{tabular}{|c|l|}
\hline Group & \multicolumn{1}{|c|}{ Voivodeships } \\
\hline I & Mazowieckie \\
\hline II & Wielkopolskie, Pomorskie, Dolnoślasskie, Zachodniopomorskie, Małopolskie \\
\hline III & Ślaskie, Lódzkie, Lubuskie, Kujawsko-pomorskie \\
\hline IV & $\begin{array}{l}\text { Opolskie, Podlaskie, Świętokrzyskie, Warmińsko-mazurskie, Lubelskie, } \\
\text { Podkarpackie }\end{array}$ \\
\hline
\end{tabular}

Source: own elaboration.

The second group includes the voivodeships on the medium-higher level of the entrepreneurship development characterized by the above average values of the following variables: the number of active non-financial enterprises per 1000 inhabitants, the number of natural persons conducting business in rural areas per 100 thou. working-age people and the average share of innovative enterprises in the total number of industrial and services sector enterprises.

The third group includes voivodeships on the medium-lower level of the entrepreneurship development characterized by the general average value of the average share of innovative enterprises in the total number of industrial and services sector enterprises.

The fourth group includes voivodeships on the low level of the entrepreneurship development, which, as in the case of the fourth typological group obtained by means of the TOPSIS method, are characterized by much lower than average values of six variables, apart from the variables regarding the 3-year income dynamics of all activities of small and medium companies, the 3 -year investment outlays dynamics of small and medium companies and the average share of innovative enterprises in the total number of industrial and services sector enterprises. 


\section{Results analysis}

Table 9. compares the rankings presenting the entrepreneurship development of the Polish voivodeships obtained by the TOPSIS method, the principal components method, as well as the ranking published in the Entrepreneurship in Poland report. The correspondence of the classifications obtained by means of all the methods in terms of the entrepreneurship development can be observed only once and it regards the Mazowieckie Voivodeship. In the case of the TOPSIS method and the principal components method, the correspondence can be observed in five cases and it regards the following voivodeships: Wielkopolskie, Małopolskie, Warmińsko-mazurskie and Lubelskie. The Podlaskie Voivodeship was ranked in the $9^{\text {th }}$ position both in the ranking of the Entrepreneurship in Poland report and in the ranking obtained by means of the TOPSIS method, and in the lower, $12^{\text {th }}$ position in the ranking obtained by means of the principal components method. The Podkarpackie Voivodeship was ranked in the $16^{\text {th }}$ position both in the ranking of the Entrepreneurship in Poland report and in the ranking obtained by means of the principal components method, and in the $12^{\text {th }}$ position in the ranking obtained by means of the TOPSIS method. In all the other cases there was no correlation between the positions in the rankings.

Apart from the rankings presenting the entrepreneurship development of the Polish voivodeships, chart 2. presents the division of the voivodeships into four typological groups in accordance with the value of the synthetic measure determined by the TOPSIS method and the principal components method. It indicates that the voivodeships located in the western part of Poland are characterized by a higher level of the entrepreneurship development than those located in the eastern part. The only exception is the Lubuskie Voivodeship which was assigned to the $4^{\text {th }}$ group in the ranking obtained by means of the TOPSIS method and to the $3^{\text {rd }}$ group in the ranking obtained by means of the principal components method. Regardless of the adopted method, ten voivodeships: Mazowieckie, Warmińsko-mazurskie, Wielkopolskie, Dolnośląskie, Zachodniopomorskie, Łódzkie, Opolskie, Świętokrzyskie, Lubelskie and Podkarpackie were assigned to the same groups.

TABLE 9

The ranking of voivodeships in terms of the entrepreneurship development according to the Entrepreneurship in Poland report, obtained by means of the TOPSIS method and the principal components method

\begin{tabular}{|l|c|c|c|}
\hline \multicolumn{1}{|c|}{ Voivodeship } & $\begin{array}{c}\text { Ranking published } \\
\text { in the Entre- } \\
\text { preneurship } \text { in } \\
\text { Poland } \text { report }\end{array}$ & $\begin{array}{c}\text { Ranking } \\
\text { obtained by } \\
\text { means of the } \\
\text { TOPSIS } \\
\text { method }\end{array}$ & $\begin{array}{c}\text { Ranking obtained } \\
\text { by means of the } \\
\text { principal } \\
\text { components method }\end{array}$ \\
\hline Mazowieckie & 1 & 1 & 1 \\
\hline Dolnośląskie & 2 & 3 & 4 \\
\hline Zachodniopomorskie & 3 & 4 & 5 \\
\hline
\end{tabular}




\begin{tabular}{|l|c|c|c|}
\hline \multicolumn{1}{|c|}{ Voivodeship } & Ranking published & Ranking & Ranking obtained \\
\hline Wielkopolskie & 4 & 2 & 2 \\
\hline Lódzkie & 5 & 7 & 8 \\
\hline Pomorskie & 6 & 5 & 3 \\
\hline Małopolskie & 7 & 6 & 6 \\
\hline Śląskie & 8 & 10 & 7 \\
\hline Podlaskie & 9 & 9 & 12 \\
\hline Opolskie & 10 & 8 & 11 \\
\hline Kujawsko-pomorskie & 11 & 13 & 10 \\
\hline Warmińsko-mazurskie & 12 & 14 & 9 \\
\hline Lubuskie & 13 & 11 & 15 \\
\hline Lubelskie & 14 & 15 & 13 \\
\hline Świętokrzyskie & 15 & 16 & 16 \\
\hline Podkarpackie & 16 & 12 & $P o /$ \\
\hline
\end{tabular}

Source: own elaboration and based on the results published in [Przedsiebiorczosí $w$ Polsce, 2017, p. 165].

The Opolskie and Podlaskie Voivodeships were ranked one typological group higher by means of the TOPSIS method than the principal components method, and the Pomorskie, Kujawsko-pomorskie, Lubuskie and Małopolskie Voivodeships - one group lower.

CHART 5

Division of the voivodeships in accordance with the classes based on the values of the synthetic measure obtained by means of the TOPSIS method (left) and the principal components method (right).
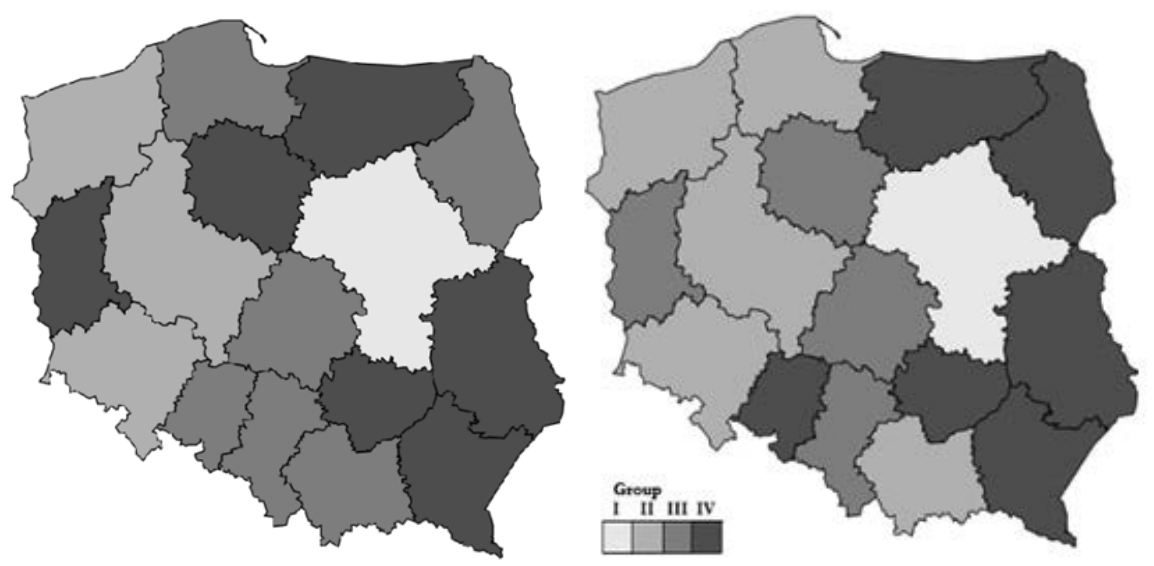

Source: own elaboration. 
By using the TOPSIS method, the principal components method or the taxonomic analysis, it has been determine that the Mazowieckie Voivodeships is an undisputed leader in terms of the entrepreneurship development, while the second class of voivodeships on the medium level of entrepreneurship includes the Wielkopolskie, Dolnoślaskie and Zachodniopomorskie Voivodeships. The third class is very diverse and there was no single voivodeship that, regardless of the method applied, was assigned to this group. The Podkarpackie, Świętokrzyskie, Warmińskomazurskie and Lubelskie Voivodeships are characterized by the lowest level of entrepreneurship.

\section{Conclusions}

The article presents the analysis of the Polish voivodeships' attractiveness in terms of the entrepreneurship development on the basis of nine variables, by means of the taxonomic analysis, the TOPSIS method and the principal components analysis. The variables, which were used to calculate synthetic measures and to define typological groups describing the entrepreneurship development, were taken from the Entrepreneurship in Poland report published by the Ministry of Development.

Undoubtedly, the voivodeships in the western part of Poland are characterized by a higher level of the entrepreneurship development. The only exception is the Lubuskie Voivodeship, which is located among the voivodeships on the mediumlower level of the entrepreneurship development. The Mazowieckie and Wielkopolskie Voivodeships are ranked in the top of the rankings obtained by means of the TOPSIS method and the principal components method, and at the other extreme, i.e. among the voivodeships on the low level of the entrepreneurship development are the voivodeships located in the south-eastern part of Poland - the Świętokrzyskie, Lubelskie and Podkarpackie Voivodeships. The Podlaskie Voivodeship was ranked in the $9^{\text {th }}$ positions in two rankings, in the Entrepreneurship Development and in the ranking obtained by means of the TOPSIS method and in the $12^{\text {th }}$ position in the ranking obtained by means of the principal components method. In terms of the typological group, regardless of the adopted method, the Podlaskie Voivodeship was assigned to the group of the voivodeships on the lower-medium level of the entrepreneurship development.

The conducted analysis proved that there are major disparities in the voivodeships' level of the entrepreneurship. It is particularly visible in the case of the comparison between the results of the voivodeships in the western part of Poland, which are characterized by a notably higher level of entrepreneurship, and those in the eastern part of the country, that is why it is important to support entrepreneurship in the eastern regions. A good method to reduce the disparities is benchmarking, in which the point of reference is the Mazowieckie Voivodeship, which is in a leadership position in Poland. 


\section{References}

Balicki A., 2013, Statystyczna analiza wielowymiarowa i jej zastosowanie spoteczno-ekonomiczne, Wydawnictwo Uniwersytetu Gdańskiego, Gdańsk.

Cox D.R., 1957, Note of grouping, "Journal of The American Statistical Association", vol. 52.

Dynamika transformacij polskiej gospodarki, 1997, Belka M., Trzeciakowski W. (red.), t. 1, Poltex, Warszawa.

Florek K., Lukaszewicz J., Perkal J., Steinhaus H., Zubrzycki S., 1956, Taksonomia wrockanska, „Przegląd Antropologiczny”, nr 17.

Hwang C.L., Yoon K., 1981, Multiple Attribute Decision Making: Methods and Applications, Springer-Verlag, Berlin.

Jabłońska M., 2017, Finansowe aspekty roz̧woju regionalnej præeedsiebiorczości, Wydawnictwo Uniwersytetu Lódzkiego, Łódź.

Jajuga K., 1993, Statystyczna analiza wielonymiarowa, PWN, Warszawa.

Kolenda M., 2006, Taksonomia numeryczna, Akademia Ekonomiczna we Wrocławiu, Wrocław.

Korol J., Kusideł E., Szczuciński P., 2016, Przedsiębiorczość, produktynność i konkurencyjność regionów Polski, Adam Marszałek, Toruń.

Lenik P., Krzywonos M., 2015, Wybrane zagadnienia przedsiębiorczości w kontekśsie historii polskiej transformacij gospodarczej, [w:] Efektywność zarzadzania zasobami organizacyjnymi, Lenik P. (red.), Zeszyt 68, PWSZ w Krośnie, Krosno.

Makieła Z., 2018, Przedsiebiorczość $i$ zarzadzanie innowacjami: wiedza, technologia, konkurencja, przedsiebiorstwo, C. H. Beck, Warszawa.

Młodak A., 2006, Analiza taksonomiczna w statystyce regionalnej, Difin, Warszawa.

Przedsiebiorczośc w Polsce, 2017, Ministerstwo Rozwoju, Warszawa.

Raport o stanie sektora malych $i$ średnich przedsiebiorstw w Polsce, 2017, PARP, Warszawa.

Sadowski Z., 2005, Dlaczego transformacji gospodarczej nie można u₹nać za zakończona, [w:] Gospodarka Polski po 15 latach transformacji, Bach Z., Pollok A. (red.), PTE, Kraków.

Skowronek C., 2010, Sektor przedsiebiorstw w procesie transformacji polskiej gospodarki, [w:] „Annales Universitatis Mariae Curie-Skłodowska, Sectio H Oeconomia”, vol. 44(1).

Strategiczna transformacja polskich firm. Od restrukturyzacji do strategii rožwoju zemnetrznego, 2012, Sroka W., Chwistecka-Dudek H. (red.), Wyższa Szkoła Biznasu w Dąbrowie Górniczej, Dąbrowa Górnicza.

Ustawa z dnia 2 lipca 2004 r o swobodzie działalności gospodarczej, Dz.U. 2004 nr 173 poz. 1807.

Zmiany strukturalne grup podmiotón gospodarki narodowej w 2007 r., 2008, GUS, Warszawa.

Zmiany strukturalne grup podmiotón gospodarki narodowej w rejestrze REGON w 2017 r., 2018, GUS, Warszawa.

Ward Jr. J.H., 1963, Hierarchical Grouping to Optimize an Objective Function, "Journal of the American Statistical Association", vol. 58. 